\title{
Obraz sacrum w utworach śpiewanych młodzieży na Zaolziu. Na przykładzie obrazu Boga, Jezusa, Maryi i postawy czlowieka wobec świętości ${ }^{1}$
}

\author{
Urszula Kolberová \\ Uniwersytet Ostrawski \\ urszula.kolberova@osu.cz
}

\begin{abstract}
Streszczenie
Tematem niniejszych rozważań stały się teksty utworów śpiewanych przez katolicka młodzież zaolziańska, a ściślej wytaniajacy się z nich obraz sacrum (ściślej Boga, Jezusa, Maryi i postawy człowieka wobec świętości), jaki przedstawia się młodemu człowiekowi terenów granicznych. Metoda badawcza wykorzystana do analiz zgromadzonego materiatu opiera sie na założeniach językowego obrazu świata. Obraz sacrum $w$ polskich $i$ czeskich utworach śpiewanych przez młodzież na Zaolziu zawiera ogólnie znany obraz Boga, Jezusa, Maryi. Bóg jest przed wszystkim dobry, wszechmogacy, zgładza grzech, jest nieskończony, jest dla człowieka ojcem, opiekunem, a człowiek winien go wielbić jako stwórcę. Podobnie Jezus jest miłosierny $i$ to poprzez niego prowadzi droga do Boga i zbawienia. Natomiast Maryja jest wielbiona przede wszystkim jako Matka Jezusa i Matka nas, ludzi. Ten ogólnie znany obraz sacrum dzięki pieśniom jest powtarzany i utrwalany. Teksty polskie i czeskie sa do siebie zasadniczo podobne $w$ ogólnym przedstawianiu sacrum, jego obrazie, jednak możemy zauważyć pewne różnice kulturowe, np. odwołania do Maryi jako Królowej Polski i ogólnie mocniej zarysowany obraz Maryi w polskich tekstach.
\end{abstract}

Słowa kluczowe: językowy obraz świata, utwory śpiewane, sacrum, Zaolzie, młodzież

Abstract

The Image of the Sacred in the Songs of Young People in Zaolzie

The subject of the present paper are the lyrics of the songs sung by Catholic youth from Zaolzie or, more precisely, the emerging image of the sacred (God, Jesus, Mary and man's attitude towards the sacred), which is presented to young people in borderland areas. The research method used to analyse the collected material is based on the methodology of the linguistic picture of the world. The image of the sacred in Polish and Czech songs in Zaolzie contains the generally known image of God, Jesus and Mary. God is above all good, almighty,

1 Artykuł powstał w ramach realizacji projektu Uniwersytetu Ostrawskiego: Obraz sacrum v jazyce křest'anské mládeže, SGS04/FF/2019-2020. 
eliminates sins, is infinite, is a father and guardian for man, and man should love him as the Creator. Similarly, Jesus is merciful and through him leads the way to God and salvation. Mary, on the other hand, is worshipped primarily as the Mother of Jesus and Mother of us, people. This generally known image of the sacred is repeated and consolidated thanks to the songs. Polish and Czech texts do not differ significantly from each other in the general presentation of the sacred and its image, but we can notice some differences, such as references to Mary as the Queen of Poland, and the generally stronger picture of Mary in Polish texts.

Key words: linguistic picture of the world, songs, the sacred, Zaolzie region, young people

\section{Wstęp}

Można zaryzykować stwierdzenie, że śpiewy od samego początku towarzyszyły chrześcijaństwu. Już od czasów antycznych rozwijały się przecież gatunki związane z muzyką, jak psalmy, hymny, pieśni, a również sama Biblia zawiera fragmenty o tym, by szerzyć Słowo Boże i uwielbienie Pana „śpiewając Bogu w waszych sercach” (List do Kolosan, Kol 3,16). Słowo śpiewane z biegiem czasu na tyle przylgnęło do liturgii, nabożeństw i wszelkich przejawów życia związanego z Kościołem i chrześcijaństwem, że dziś trudno wyobrazić sobie przebieg mszy świętej bez pieśni wykonywanych przy akompaniamencie organów bądź śpiewu chóru kościelnego lub spotkania młodzieżowe, oazowe bez wesołych śpiewów i towarzyszącej im gitary.

Tematem niniejszych rozważań stały się teksty utworów śpiewanych przez katolicką młodzież zaolziańską, a ściślej wyłaniający się z nich obraz sacrum, (konkretnie zaś Boga, Jezusa, Maryi i postawy, jaką winien przyjmować człowiek wobec świętości), jaki przedstawia się on młodemu człowiekowi terenów granicznych. Zaolzie to teren w Republice Czeskiej (za rzeką Olzą) w dużej mierze zamieszkiwany przez mniejszość polską. Liturgia w kościołach (tak katolickich, jak ewangelickich) jest tutaj odprawiana w obu językach - polskim i czeskich. Polacy mieszkający na tym terenie są dwujęzyczni.

\section{Założenia, materiał badawczy, analiza}

Teksty utworów poddano analizie wykorzystując założenia językowego obrazu świata (JOS), rozumiejąc go za Jerzym Bartmińskim jako: „obraz naiwny, leżący u podstaw języka, utrwalony w strukturze gramatycznej i znaczeniach słów, a także w strukturze i znaczeniach tekstów" (Bartmiński 2012: 16). Podobnie JOS w pracy Językowy obraz świata a spójność tekstu wydanej w tomie Teoria tekstu w 1986 r. definiuje Jerzy Bartmiński razem z Ryszardem Tokarskim, jako ,pewien zespół sądów mniej lub bardziej utrwalonych w języku, zawartych 
w znaczeniach wyrazów lub przez te znaczenia implikowanych, który orzeka o cechach i sposobach istnienia obiektów świata pozajęzykowego. W tym sensie JOS jest utrwaleniem zespołu relacji zawartych w językowym ukształtowaniu tekstu, a wynikających z wiedzy o świecie pozajęzykowym” (Bartmiński, Tokarski 1986: 72). Kontynuując powyższe Bartmiński zauważa, że w języku zawarta jest swoista „różnie zwerbalizowaną interpretacją rzeczywistości dającą się ująć w postaci zespołu sądów o świecie. Mogą to być sądy „utrwalone” w gramatyce, słownictwie, w kliszowych tekstach np. przysłowiach, ale także sądy „presuponowane”, tj. implikowane przez formy językowe utrwalonej na poziomie społecznej wiedzy, przekonań, mitów, rytuałów" (Bartmiński 1999: 104). Jeszcze inna definicja ujmuje JOS jako ,strukturę pojęciową utrwaloną (zakrzepłą) w systemie danego języka" (Grzegorczykowa 1999: 41). Struktura ta utrwalona jest zarówno we właściwościach leksykalnych, jak i gramatycznych języka, czyli w znaczeniach wyrazów oraz ich łączliwości. Natomiast koncepcja Janusza Anusiewicza kieruje się w stronę interpretacyjnej funkcji języka wobec rzeczywistości i tłumaczy JOS jako ,podsumowanie i zestawienie codziennych doświadczeń i przyjętych, tudzież zaakceptowanych przez daną wspólnotę komunikatywną norm, wartości, sposobów wartościowania oraz wyobrażeń i nastawień wobec tej rzeczywistości i to zarówno materialnej jak i duchowej, psychicznej, świadomościowej, wewnętrznej” (Anusiewicz 1994: 24-25). Anusiewicz wskazywał na wpisane w język doświadczenia pokoleń i ich realizację u kolejnych generacji. I właśnie na leksykalnym aspekcie JOS utrwalanym i powtarzanym przez pokolenia pragniemy skupić swoje badania i analizę.

Materiałem badawczym stały się teksty w śpiewnikach, z którymi spotyka się młodzież katolicka na terenie Zaolzia, i z których śpiewa utwory podczas mszy św., spotkań młodzieży katolickiej, pielgrzymek, w chórach młodzieżowych itp. Zebrany materiał to przede wszystkim teksty zawarte w polskim śpiewniku Exsultate Deo, czeskim śpiewniku Koinonia oraz luźno zebrane teksty². Łącznie analizie poddano 735 tekstów polskich i 330 czeskich.

Materiałem badawczym w niniejszym artykule są teksty utworów śpiewanych, czyli pieśni i piosenek religijnych. Dzisiaj śpiewane są one nie tylko podczas mszy, ale również podczas spotkań młodzieży, pielgrzymek, oaz itp. Powstały one na podłożu śpiewów liturgicznych, których rodowód charakteryzuje Teresa Michałowska następująco: „były utworami słownomuzycznymi, przeznaczonymi do wykonywania chóralnego w obrębie nabożeństwa; mógł je

\footnotetext{
${ }^{2}$ Cały polski i czeski materiał badawczy został udostępniony dzięki uprzejmości dr Terezy Ondruszovej samodzielnego asystenta w parafii karwińskiej.
} 
odśpiewywać chór kantorów, czasem dwa chóry naprzemiennie, niekiedy chór na zmianę z celebransem. Wyrażały one zbiorowe emocje religijne. Zawierały przeważnie prośby o łaskę, opiekę lub wstawiennictwo, kierowane do Boga lub świętych, a równocześnie liczne elementy pochwalne. Odznaczały się stylem prostym, dalekim od retorycznej ozdobności” (Michałowska 2000: 211). Natomiast śpiew wiernych do obrządku kościelnego w języku narodowym przenikał wolno i od XVI w. stopniowo utrwalał się w niektórych częściach nabożeństwa (Michałowska 2000: 341). Natomiast odnośnie do współczesnej pieśni religijnej Agnieszka Sojka w publikacji Człowiek $i$ Bóg $w$ pieśni. Studium antropologicznopedagogiczne tę formę charakteryzuje jako wypowiedź ,słowno-muzyczną [...] i akt komunikacji językowej” (Sojka 2008: 33). Dalej ta sama autorka wskazuje na trzy elementy konstytuujące fenomen pieśni religijnej, którymi są: treść, charakter i przeżycie oraz przybliża pieśń religijną w kulturze europejskiej jako ,utwór wyrażający potrzeby człowieka, jego przeżycia religijne; jest zarazem formą zwrotu do Boga. Związek treści z tematyką religijną polega na posługiwaniu się pojęciami teologicznymi lub zwrotami odwołującymi się do pobożności ludowej; treścią są prawdy wiary” (Sojka 2008: 30).

Natomiast różnica pomiędzy pieśnią a piosenką sprowadza się przede wszystkim do powagi, charakteru wykonania czy odtworzenia. Pieśń religijna charakteryzuje się poważną kompozycją, a jej wykonanie jest artystyczne, możemy się z nią spotkać podczas liturgii, podobnie jak z pieśnią kościelną śpiewaną przez wierzących, natomiast piosenka religijna ma charakter wesoły, swobodny i jest przeznaczona na pielgrzymki, spotkania, festiwale itp. (za Rojewski 2010: 364; Pawlak 1973: 212). Jeżeli chodzi o tekst, to teksty pieśni są w miarę proste, choć niepozbawione przenośni, analogii, apostrof itp. Natomiast w tekstach piosenek kładzie się większy nacisk na sytuacje życiowe, własne przeżycia, często pojawiają się refleksje filozoficzne, dotyczące sensu życia, szczęścia lub niepokoju³ ${ }^{3}$ Piosenka najczęściej pełni funkcję ekspresyjną, jej celem staje się rozrywka, rzadziej oddanie czci Bogu, natomiast styl piosenek religijnych nawiązuje często do stylu piosenek świeckich, festiwalowych, rockowych, popowych, rapowych, metalowych ${ }^{4}$. Pomimo zarysowanego tu formalnego rozróżnienia należy zaznaczyć, że granica między pieśnią a piosenką jest w miarę płynna ${ }^{5}$.

Natomiast skupiając się na samych tekstach utworów śpiewanych można ogólnie powiedzieć, że nie powinny być skomplikowane, by łatwiej zapadały w pamięć, figury

\footnotetext{
${ }^{3}$ Por.: http://muzyka-koscielna.pl/piesn-a-piosenka/. Data ostatniego dostępu: 24.02.2020.

${ }^{4}$ Por.: http://spiewniksiedleckiego.pl/wp-content/uploads/spiewy-w-liturgii.pdf. Data ostatniego dostępu: 24.2.2020.

${ }^{5}$ Por.: http://muzyka-koscielna.pl/piesn-a-piosenka/. Data ostatniego dostępu: 24.02.2020.
} 
stylistyczne i różnego rodzaju ozdobniki powinny być raczej proste i jasne, bowiem powinni je zrozumieć wszyscy wierni ${ }^{6}$.

Młodzież chętnie śpiewa pieśni i piosenki religijne z tekstów, z których tym samym wyłania się szeroko rozumiany obraz sacrum. Jak zatem przedstawia się on w tekstach utworów śpiewanych przez polskojęzyczną młodzież katolicką na Zaolziu, która z racji bilingwizmu może korzystać z polskich i czeskich tekstów? Oczywiście nie ulega wątpliwości, że obraz sacrum będzie przedstawiony pozytywnie tak przez polskie, jak i czeskie śpiewniki i będzie raczej podobny, gdyż chodzi przeniesienie do pieśni akceptowanych w katolicyzmie elementów doktryny katolickiej „W pieśń religijną wpisany jest określony świat czy nawet światopogląd odnoszący się do świadomości istnienia Boga; jest to świat wiary wspólny odbiorcy i nadawcy. Charakter gatunku, jakim jest pieśń religijna, nadaje mu pewien światopogląd. Odbijają się w nim treści świadomości podmiotu mówiącego i odbiorcy” (Sojka 2008: 41). Pytaniem, na które chcemy znaleźć odpowiedź, to jak przedstawia się ogólny,

${ }^{6}$ Jak pisze ks. Karol Mrowiec: tekst musi być przystępny, ale nie może być prymitywny, nie może posługiwać się staroświeckim językiem, który nie byłby w pełni zrozumiały lub wymagałby wiele objaśnień, dalej tekst nie może być tylko rymowaną teologią, ani wyłącznie "fascynującą poezją" z fałszywą teologią (Mrowiec 1978: 149). Natomiast ks. Stanisław Ziemiański pisze, że tekst powinien wyrażać modlitwę w różnych jej funkcjach (prośba, dziękczynienie, przepraszanie, chwała, skarga) i podporządkować element egzystencjalny relacji do Boga (por.: http://muzyka-koscielna.pl/piesn-a-piosenka/. Data ostatniego dostępu: 24.02.2020), a ks. Wojciech Kałamarz dodaje, że tekst powinien zawierać właściwy rytm, w sensie akcentów słownych i emocjonalnych, będący ważnym czynnikiem współtworzącym pieśń (por.: http://spiewniksiedleckiego.pl/wp-content/uploads/spiewyw-liturgii.pdf. Data ostatniego dostępu: 24.02.2020). W sprawie pieśni i muzyki im towarzyszącej wypowiadały się w przeszłości największe autorytety kościoła, jak np. Papieże (przykładowo wystarczy wspomnieć Piusa X, encyklikę Piusa XII Musicae sacrae disciplina, o ważności muzyki kościelnej mówi też Jan Paweł II w encyklice Ecclesia de Eucharistia lub Benedykt XVI w adhortacji apostolskiej Sanramentum Caritatis.), zagadnienia te były poruszane przez Stolicę Apostolską bądź też na soborach i synodach (por. instrukcję Świętej Kongregacji Obrzędów Musicam Sacram), kwestie związane z muzyką poruszał II Sobór Watykański, dalej wiele synodów w Polsce (w Tarnowie 1948, w Przemyślu 1955, więcej na ten temat por.: ks. Władysław Padacz, Śpiew i muzyka kościelna w świetle statutów powojennych synodów diecezjalnych, „Ruch Biblijny i Liturgiczny” 1958, t. 11, nr 6, s. 498-506). Tematem młodzieży i dzieci zajmowały się także Synody Biskupów (np. na IV i XV Zwyczajnym Zgromadzeniu Ogólnym w 1977 i 2018 r.). Niektóre z nich zwracały uwagę w tym kontekście również na osoby młode, a nawet dzieci. Wystarczy przypomnieć na przykład synod częstochowski z 1954 r., którego jednym z zaleceń było, aby podczas mszy śpiewać nabożne pieśni, a kolejne zalecenie kierowane było do organistów, który powinni uczyć dzieci, młodzież oraz dorosłych śpiewu kościelnego podczas coniedzielnych mszy. Szczególnie młodzież w okresie dorastania odczuwa potrzebę społecznej przynależności i akceptacji grona rówieśników. Potrzeby te spełnia nie tylko szkoła, lecz również organizacje pozaszkolne, nie wyłączając tych katolickich. Tutaj spotkania rówieśników mogą realizować się, w zależności od zainteresowań, np. w działalności chóralnej, pielgrzymkach, spotkaniach „z gitarą“, oazach, spotkaniach młodzieży katolickiej, itp. Wszystkim tym aktywnościom często towarzyszy śpiew. Jak zauważa Agnieszka Wysocka: „w okresie dorastania każdy prawidłowo rozwijający się człowiek jest otwarty na przeżycia i doświadczenia estetyczno-emocjonalne związane z muzyką. [...] Młodzież szuka w muzyce przede wszystkim możliwości przeżyć, wzruszeń, odreagowania narastających stresów emocjonalnych, charakterystycznych dla tego okresu" (por.: http://www.edukacyine.dyskursy.univ.szczecin.pl/aktywnosc.htm. Data ostatniego dostępu: 27.02.2020).

Na popularność muzyki w okresie dorastania u młodych zwracają uwagę również inni badacze mówiąc, że „zaczyna [ona] zajmować w życiu młodzieży miejsce szczególne i wymieniana jest przez nią jako jedna z najważniejszych dziedzin zainteresowań i aktywności w czasie wolnym" (Monturzewska, Kotarska 1990: 45). 
podstawowy obraz sacrum, czyli obraz Boga, Jezusa, Maryi, a także obraz stosunku człowieka do świętości. Taki obraz młody człowiek i wykonawca utworów przyjmuje podświadomie odtwarzając teksty utworów śpiewanych.

Śpiewnik Exultate Deo zawiera 661 tekstów w języku polskim ${ }^{7}$. Do analizy wykorzystano wydanie dziesiąte z 2010 r. opublikowane przez krakowskie Wydawnictwo Światło-Życie. Zbiór ten w parafiach zaolziańskich bywa wykorzystywany jako śpiewnik oazowy lub stosowany przez schole podczas mszy i nabożeństw ${ }^{8}$. Jeżeli chodzi o czeskie pieśni popularne wśród młodzieży, to $\mathrm{w}$ ostatnich latach sporym zainteresowaniem cieszą się utwory przejmowane właśnie od Polaków. Czesi znają Magdę Aniol ${ }^{9}$, Arkę Noego ${ }^{10}$, teksty tej ostatniej grupy można znaleźć wraz $\mathrm{z}$ czeskimi tłumaczeniami na czeskich stronach internetowych ${ }^{11}$. Bodajże najbardziej popularnym śpiewnikiem wśród czeskiej katolickiej młodzieży jest Koinonia, która w 2016 r. doczekała się już ósmego wydania ${ }^{12}$. W opisie czytamy, że chodzi o śpiewnik przeznaczony do liturgii i modlitwy, a wszystkie pieśni tam zamieszczone spełniają wymogi dokumentu Konferencji Biskupów Czeskich pt. Zbiór zaleceń do korzystania z muzyki liturgicznej podczas nabożeństw, zwłaszcza w związku z młodzieża. ${ }^{13}$ W śpiewniku, który zawiera 229 tekstów piosenek, można znaleźć utwory mające już tradycyjnie swe miejsce $\mathrm{w}$ tym śpiewniku i tym samym znane od pokoleń, natomiast do ostatnich wydań coraz częściej powracają teksty starsze, które kojarzą ze swoich młodych lat dziś już osoby w podeszłym wieku ${ }^{14}$. W obu śpiewnikach najwięcej miejsca zajmuje tu Bóg, któremu towarzyszą takie przymiotniki, jak litościwy; wszechmogący; najwyższy; prawdziwy; łaskawy; niepojęty. Rzeczowniki, którymi jest określany, to na przykład Ojciec; Stworzyciel; Władca; uzdrowiciel; wśród połączeń wyrazowych pojawia się Król łaskawy; Pan wszechstworzenia; Król królujących, Pan panujacych; dawca życia; dawca wszystkiego

\footnotetext{
7 Śpiewnik zawiera 746 pieśni w języku polskim i łacińskim, niektóre teksty wystąpiły/zostały powtórzone w kilku wariantach muzycznych, analiza nie objęła łacińskojęzycznych utworów, stąd analiza objęła 661 tekstów.

${ }^{8} \mathrm{Wg}$ rozmowy z Terezą Ondruszovą, samodzielnym asystentem w parafii karwińskiej.

${ }^{9}$ Przykładowo na temat Magdy Anioł piszą czeskie strony, por.: http://old.in.cz/clanky/hudba/magda-anioxdv.htm. Data ostatniego dostępu: 28.02.2020; http://hudba.signaly.cz/interpreti/1021-magda-aniolpochopila-jsem-ze-misto-odsouzeni-sebe-musim-dekovat-bohu-za-novy-zivot-s-nim.html. Data ostatniego dostępu: 28.02.2020; https://test.in.cz/soubory/2011/04/nahled-casopisu-in-kveten-201118-tuk.pdf. Data ostatniego dostępu: 28.02.2020.

${ }^{10} \mathrm{Na}$ temat Arki Noego piszą czeskie strony, por.: http://hudba.signaly.cz/interpreti/497-poznejte-bli-arkunoego.html. Data ostatniego dostępu: 28.02.2020; http://hudba.signaly.cz/interpreti/60-arka-noego.html. Data ostatniego dostępu: 28.02.2020; http://www.rodinnyzivot.eu/index.php/napln-casopisu/rozhovor/111-kdyarcha-zp-nikdo-nez. Data ostatniego dostępu: 28.02.2020.

${ }^{11}$ Por.: https://www.karaoketexty.cz/texty-pisni/arka-noego-12941. Data ostatniego dostępu: 28.02.2020.

12 Wydawcą jest Arcybiskupstwo Ołomunieckie, redakcją odpowiedzialną Archidiecezjalne Centrum dla Młodzieży Ołomuniec. Pierwsze wydanie $1993 \mathrm{r}$.

${ }^{13}$ Soubor doporučeni pro používání liturgické hudby při bohoslužbách, zvláště ve vztahu k mládeži.

${ }^{14}$ Za: rozmową z Terezą Ondruszovą w czerwcu 2019 r.
} 
dobrego, dalej jest On pełen miłosierdzia; petny chwały; zgładza nieprawość; obmywa z winy; oczyszcza z grzechu; zgładza grzechy. Już z powyższych krótkich określeń można wywnioskować wyższość Boga nie tylko w stosunku do człowieka, ale wszystkiego na świecie, wyższą frekwencją wyróżniają się również połączenia dotyczące Boga jako dawcy życia, życia wiecznego oraz tego, który zgładza grzech, ratuje człowieka od grzechu. Dalej podkreślana jest Jego ciągłość, wieczność czy trwałość poprzez takie określenia, jak Tyś początkiem wszystkiego; jedyny majacy nieśmiertelność; żyje na wieki; Bóg ojców naszych; zrodzony przed wszystkimi wiekami; imię Twoje wywyższone na wieki; nieśmiertelny Panie, to wszystko bywa uzupełniane powszechnie znanym: Jak było na początku, teraz i zawsze i na wieki wieków. Amen. Bóg przedstawiany jest również jako sędzia, przy czym podkreślana jest jego sprawiedliwość: sprawiedliwie sądzi ludy; jego wyroki sa sprawiedliwe i prawdziwe. Dalej Bóg wyobrażany jest jako opiekuńczy Ojciec, nauczyciel i obrońca. Zauważyć to możemy w następujących określeniach: Ty z miłości ojcowskiej stworzyłeś człowieka; w Twych otwartych ramionach; rozprasza grozę śmierci tym, co żyja w mroku; oświeca tych, co w mroku i cieniu śmierci mieszkają; wyzwolit lud swój wybrany; wybawi od nieprzyjaciót. Bóg kojarzony jest ze światłem, światłością, blaskiem, co obrazują następujące przykłady: Słońce prawdy; w Tobie źródło jest jasności; stwarzasz światto; naród kroczacy w ciemnościach ujrzat świattość wielka. Pomimo wszystkich wymienionych superlatywów i wrażenia bliskości, Bóg jednak zostaje niedostępny i tajemniczy, co zawarte jest w następującym: którego żaden z ludzi nie widział ani nie może zobaczyć lub Kościół Cię nie ogarnie. Pojawiają się również informacje o miejscu przebywania Boga, znów niedostępną dla śmiertelnika, mianowicie: zamieszkuje światłość niedostępna; na tronie swego królestwa zasiada na Cherubach na sklepieniu nieba. W czeskim śpiewniku Bóg określany jest jako Král, Pán, Otec, Stvořitel, oprócz tych leksemów w języku czeskim równie częstym jest Hospodin. Potęgę Boga wyrażają przymiotniki jak: všemocný; všemohoucí; nejvyšší; oraz inne określenia zwracające uwagę na jego wielkość i nieskończoność, jak: věčný tvůrce; Alfa, Omega; v něm vše začíná i končí... Teksty utworów wyrażają również należytą cześć oddawaną Bogu, czytamy w nich, że Bóg jest hoden úcty; bud' pochválen, Pane můj, jest On również slitovný a spravedlný, laskavý, czyli podkreślana jest jego rola, jako łaskawego i sprawiedliwego sędziego. Bóg jest obrońcą człowieka, zapewnia mu bezpieczeństwo: Bůh je můj štit, on mne vysvobodí, smím žít ve stínu kř́del Tvých; do stínu kř́del Tvých se ukrývám; bud' mi, Pane, oporou. Dzięki Bogu życie człowieka zyskuje harmonię, ład, człowiek staje się lepszym, przykładem może być następujący urywek: lásku, pokoj v duši nacházím. 
Bardzo dużo miejsca poświęcone zostało również Jezusowi, któremu po części towarzyszą podobne wyrażenia co Bogu. Jak Bóg jest on dobry; miłosierny; jest nazywany Królem chwały; Dobrym Pasterzem. Podkreślana jest jego rola jako zbawiciela, co zawarło się w określeniach, jak Zbawiciel; który daje z grzechów powstać; wzywa grzeszników; wstawia się za ludem swoim; prowadzi w niebios bramy; przebacza tym, którzy widza swój grzech, zgnębionych wydobywa z mroku, szuka zaginionych i prowadzi w dom Ojca. Jest On zatem przewodnikiem, obrońcą, poprzez niego dokonuje się zbawienie i przebaczenie. Podobnie jak w przypadku Boga również w kontekście Jezusa podkreślana jest ciągłość i trwałość, co przejawia się w połączeniach słownych, jak: Król wieków; Król wiecznej chwały; nazywany jest Synem Rodzica z wiek wieka; swój lud będzie On bronić po wszystkie lata; dalej jest On również sędzią: przyjdziesz sądzić ludzkie czyny. Podkreślane jest Jego zwycięstwo nad śmiercią, np. pokruszyt śmierci wrota lub człowieczeństwo, np. przyoblókt się w człowieka. Również w jego kontekście pojawia się światło lub światłość: rzucit światło na życie przez Ewangelię; wezwat nas z ciemności do swojego prawdziwego światła. W tekstach czeskich Jezus najczęściej nazywany jest tradycyjnymi określeniami Boží Syn; Spasitel (czyli Zbawiciel), Pán; Mesiáš; vykupitel; Mistr; prítel, połączenia wyrazowe to przykładowo Dobrý Pastýř, a wśród bardziej poetyckich określeń znalazły się przykładowo: slunce spravedlnosti; chléb živý. Imię Jezusa łączone jest z pozytywnymi aspektami wiary: Pán je má naděje víra, láska, radost. Jego wyższość i potwierdzenie tego, że jest królem znajdujemy w słowach: Ježíš králuje nad vší zemí; národy se Tobě vděčně pokloní. Jezus jest oparciem dla człowieka w trudnych chwilach, daje poczucie bezpieczeństwa, można powierzyć mu swój los. Powyższe znajduje potwierdzenie w słowach: Pán mi sílu dává; s ním nemusím se bát; trápení svá na Pána vkládám, dzięki niemu człowiek dostąpi zbawienia: nás doprovodi k Otci Kristus Pán, bowiem tylko On jest tą właściwą drogą: jedina cesta $k$ životu, $k$ pravdě, $k$ vitězství. Jezus jest dla człowieka opiekunem, w tym kontekście często przywołany zostaje pasterz: K ovcím ztracených stád vcházi Ježíš; Dobrého Pastýře znám, On vodí ovce své k pramenům spásy. Z Jezusem łączy się również przebaczenie za winy ludzkie: naše skutky zlé Tys nám odpustil Jezus kocha człowieka, co znajduje potwierdzenie w licznych tekstach: On je náš Pán, miluje nás, žehná nám... láska Tvá je velká; Ty miluješ nás; Ježǐš má mne rád. W kontekście Jezusa pojawia się wdzięczność dotycząca uzyskania życia wiecznego dzięki zmartwychwstaniu pańskiemu: on z hrobu vstal, život mi dal; zlomil smrti moc.

Dużo miejsca w tekstach pieśni zajmuje również Maryja. Wśród jednowyrazowych określeń najczęściej występują te oznaczające Maryję jako: Matkę; Bogarodzicę; Królową. Słowa i połączenia wyrazowe najczęściej spotykane w kontekście Maryi jako Matki znajdują 
potwierdzenie w takich, jak: Matka ludzi; my Twe dzieci i poddani; Tyś zawsze Matka nam; Matka miłości; Dzieciom Twym wygnanym daj matczyna dłoń; prowadź Matko swoje dzieci; bądź nam Matka, takie określenia Maryi jako Matki ludzi wierzących występują równie często, jak te dotyczące Maryi jako Matki Chrystusa; Matki Boga Najwyższego. Maryja jako matka jest wyjątkowa: ze wszystkich matek wybrana. Podkreślana jest doniosła rola Maryi jako Bożej Rodzicielki, gdyż w tekście jednej z pieśni pojawia się następujące: dzięki Tobie wśród ludu swego, chciał zamieszkać sam Bóg. Dalej Maryja pojawia się przede wszystkim w kontekście dziewictwa i jest określana przymiotnikami, jak niepokalana; nieskalana; najczystsza oraz w połączeniach wyrazowych, jak: dziewica nad dziewicami; Panna czysta. Dalej towarzyszą jej określenia, jak: przechwalebna; przebłoga; wywyższona przez Boga; nad Anioły wywyższona; z wszystkich niewiast wybrana, które świadczą o tym, że jest ona wyjątkowa i zajmuje w katolicyzmie polskim pierwszorzędną rolę. Maryja jest nazywana także: Panią światta; Pania nieba; Królowa Anielską; Furta rajską; Gwiazdą. Maryja jest również pośredniczką ludzi u Boga, co uwidacznia się przykładowo w słowach: Bóg przez Ciebie nas wystucha; orędowniczko grzeszników, prowadzi świattem łask, dalej prowadzi do światła wiary; jest nam obrona. Maryja pojawia się często w kontekście dwóch kwiatów, jest nazywana Lilija lub też w pieśniach wierni śpiewają: różami uwieńczmy jej skroń. W polskich realiach Maryja pojawia się często jako Królowa Polski i jest nazywana również Jasnogórska można Pani; Matka Boża z Częstochowy, z Ostrej Bramy i z Warszawy, uczyń Polskę ludem nowym. W tekstach czeskich Maryi towarzyszą metaforyczne określenia, jak naděje v nouzi; Panna přesvatá; Panna pokorná; prriklad lásky; celá sluncem oděná. Maryja łączona jest ze światłem i prowadzeniem człowieka do światłości: Temnotou s Marii projdeme snáz, rozžíhá svíce v nás, Jí patři dík, že Věčné Světlo nám hoří v kostelích. Prowadzi również człowieka do Jezusa i wstawia się za nim u swego syna: ved' mě k Synu svému cestou jedinou; oroduj za nás; Maria přimlouvá se za nás. Maryja stanowi również wzór dla człowieka w postępowaniu: v Tobě svioj vzor nám; chceme žít jako Maria, pokorou krásná, láskou vítězicí je naši milovanou Matkou, co zwraca równocześnie uwagę na postrzeganie jej jako Matki ludzi wierzących.

Obraz Ducha Świętego nie jest tak mocno zarysowany jak powyżej przedstawionych. Pojawia się on sporadycznie raczej w kontekście Boga czy Jezusa, uzupełniając obraz Trójcy Świętej. Duch Święty łączony jest ze światłością, a przede wszystkim z ogniem (Duchu Ogniu, Duchu Żarze, Duchu Blasku, Duchu Światło; Duchu najświętszy, oświeć mnie nędznego; Tyś jest świattem serca człowieczego), dalej również z oświeceniem, nauką i prawdą: oświeć rozum, rozjaśnij ma myśl. Obrazu świętych w analizowanym materiale praktycznie brak. Tak samo istoty stojące w opozycji do świętości, oczywiście wyobrażane negatywnie, jak diabel, 
demony pojawiają się $\mathrm{w}$ tekstach sporadycznie i zawsze jako pokonane: wstrzyma groźny cios szatana; pokonawszy szatana przywracasz życie; gdy swoja moca podeptat szatana, księcia ciemności. Podobnie jak w polskich utworach śpiewanych również te czeskie poświęcają mniej miejsca Duchowi Świętemu i istotom stojącym w opozycji do świętości, podobnie brakuje obrazu innych świętych. Duch Święty uzupełnia obraz Trójcy świętej: Duchem svatým provázíš, Pane... Tradycyjny obraz istot piekielnych i ich nicości wobec Boga manifestuje się przykładowo w następującym: Před Boži svátostí d'ábel pryč utíká; Je dokonáno, Ježiš je vítěz! Satan je poražen. Podobnie jak w tekstach polskich istoty te $\mathrm{w}$ tekstach pieśni ukazane są jako pokonane.

Obraz sacrum w utworach śpiewanych jest w dużej mierze przedstawiony również za pośrednictwem człowieka, a ściślej tego, jak powinien się w stosunku do Boga i świętości zachowywać. Tutaj przejawia się przede wszystkim wyższość Boga. Człowiek powinien służyć tylko Bogu; stawić imię Jego; głosić jego chwałę; oddawać jemu chwałe; wychwalać Go; istnieć ku chwale Jego Majestatu. Człowiek powinien się korzyć przed Bogiem, jest jego sługą (chwalcie Boga naszego wszyscy Jego studzy), nic niewartym żebrakiem (tym, co żebrza Twojej opieki) lub po prostu grzesznikiem (obwieszczam narodowi grzeszników Jego moc i wielkość). Człowiek bez obecności Boga jest zagubiony i nic nie warty, poszczególne teksty wyrażają to następująco: myśmy grzeszni i nieczyści; zgubione owce; biedni grzesznicy; grzechu niewolnicy. Dzięki Bogu człowiek powstaje z grzechu i ma możliwość dostąpienia łaski pańskiej, co zawarte jest w słowach śpiewanych podczas każdej mszy świętej: błogosławiony, który idzie $w$ imię Pańskie. Dalej człowiek odbiera Boga jako swego ojca, co wyraża następujące: jesteśmy Twoimi dziećmi; my, dzieci wiary; dom naszego Ojca; pragnie Go jak sierota rodzica: my, lud sierocy. Obraz sacrum przedstawiany za pośrednictwem tego, jaki stosunek powinien mieć do niego człowiek i jak się względem niego zachowywać, jest w czeskich tekstach mocniej zarysowany niż polskich. W licznych pieśniach jest wyrażane zaproszenie, zachęta do przyjścia, pragnienie bliskości (np. Jezusa): přijd’ Duchu svatý, my Tě zveme, príijd k nám; vzývám Tě; vejdi do mého srdce, vzývám a slavím Tvé jméno; přijd' Pane Ježíši, přijd' pro církev svou, přijd', Pane, do našich srdcí. Pochwała i oddawanie czci zawarło się przykładowo w następujących połączeniach: chválu vzdejme; chválí Tě srdce; chválím Tě, slavím Tě; osvujeme Otce všemocného; oslavujeme Hospodina; každé koleno at’ poklekne a každý jazyk vyzná, že Ježíš Kristus je Pán. Dużo miejsca w procesie wysławiania sacrum zajmuje sama czynność śpiewania: zazpívejme svému Králi; učíme se Pána vzývat, jeho chválit, jemu zpívat; pěj chválu nádhernému Pánu; chceme Ti zazpívat Bože náš; radostně zpíváme o Tvém díle; Písní k Tobě volám. Niemal w każdym tekście śpiewnika jest wskazówka odnośnie 
do tego, jak człowiek powinien się zachowywać w stosunku do sacrum. Człowiek powinien Boga chwalić, wywyższać, korzyć się przed nim, klękać, kłaniać i Jemu służyć. Jako przykład mogą posłużyć nie tylko określenia zaczerpnięte z tekstów utworów (np. a já Ti sloužit chci), ale nawet same ich nazwy: Vyvyšuj svého Pána; Oslavujme Hospodina; Nyní pokloňme se pred Králem; Klaníme se před Tvou tváří Kleč́m tu, Pane, před Tvou tvář́, a miejsce człowieka jest, zgodnie z kolejnymi nazwami utworów: Tady u Tvých nohou; Na kolenou. Liczne powyższe czasowniki i użyta forma trybu rozkazującego dynamizują teksty, wydając konkretne polecenia.

Warto na koniec naszych rozważań przybliżyć jeszcze specyfikę piosenek młodzieżowych, oazowych, pielgrzymkowych. Tutaj, oprócz żywszej, mniej poważnej muzyki, najczęściej przy akompaniamencie gitarowym, pojawiają się teksty bardziej skierowane na życie, z większą liczbą bardziej rozbudowanych metafor. Czasem, gdyby zamienić imię Pana innym, jakimś konkretnym imieniem człowieka lub liczbę mnogą zastąpić pojedynczą, to tekst taki przypominałby niemal słowa piosenki miłosnej. Potwierdzeniem może być następujący utwór:

$$
\begin{gathered}
\text { Przyjdź jak deszcz, ożyw dziś } \\
\text { Suchą ziemię naszych serc. } \\
\text { Przyjdź jak deszcz } \\
\text { Na spragniony świat. } \\
\text { Dotknij nas tak jak wiatr, } \\
\text { Rozpędź smutek, otrzyj łzy, }
\end{gathered}
$$

Zabierz tam, gdzie się w radość zmienia strach.

$$
\begin{aligned}
& \text { Wszystko dziś } \\
& \text { Nowe staje się. } \\
& \text { Panie, przyjdź } \\
& \text { I napełnij mnie! }
\end{aligned}
$$

Niemal w każdym tekście podkreślana jest potrzeba bliskości Boga, poszukiwanie Jezusa. Obrazują to następujące słowa: Gdy doświadczam bliskości Twojej; W Twej obecności Panie przebywać zawsze chcę; Przygarnij mnie do serca; Bądź przy mnie blisko; Przychodzisz, Panie, mimo drzwi zamkniętych. Pomimo tej bliskości i wrażenia ojcowskiej opieki Bóg jest wszechpotężny, co ujawnia się przykładowo w następujących wersach: Patrzę na Króla chwaty, W ogniu z nieba zbliża się A ziemia drży, a ziemia drży... lub też inny utwór: To on nasz Pan i Król, odziany w majestat swój, Okrywa światłość go, ucieka ciemność i zło... 
Pojawiają się również teksty, które bezpośrednio odwołują się do regionu zaolziańskiego, chodzi o piosenki wykonywane podczas pielgrzymek:

Rzeki przeptynątem, góry pokonatem,

Ale takiej grupy jeszcze nie spotkałem,

Bo to jest Zaolzi, grupa tak wspaniała,

Która sobie idzie na spotkanie Pana.

I inna:

Pielgrzymka z Zaolzia wielbi Maryję,

Pielgrzymka z Zaolzia śpiewa jej cześć.

Powędruj z nami polami, lasami

Przed tron Bożej Matki,

By chwałę jej nieść.

\section{Wnioski}

Podsumowując, uświadamiamy sobie nierówną ilość analizowanego polskiego i czeskiego materiału, jednak podczas analizy zauważyć można powielanie w kolejnych tekstach przybliżanego i prezentowanego obrazu sacrum. Różnicę ilościową można tłumaczyć mocniejszą tradycją katolicką w Polsce, aniżeli w raczej ateistycznych Czechach, stąd śpiewniki wydawane w Polsce są liczniejsze, zawierają więcej tekstów, są ogólnie łatwiej dostępne za sprawą większej ilości wydawnictw katolickich, odbiorca ma większy wybór. Obraz sacrum w polskich i czeskich utworach śpiewanych przez młodzież na Zaolziu zawiera ogólnie znany obraz Boga, Jezusa, Maryi. Bóg jest przed wszystkim dobry, wszechmogący, zgładza grzech, jest nieskończony, jest dla człowieka ojcem, opiekunem, a człowiek winien go wielbić jako stwórcę. Podobnie Jezus jest miłosierny i to poprzez niego prowadzi droga do Boga i zbawienia. Natomiast Maryja jest wielbiona przede wszystkim jako Matka Jezusa i Matka nas, ludzi. Ten ogólnie znany obraz sacrum dzięki pieśniom jest powtarzany i utrwalany.

Teksty pieśni w obu językach są przede wszystkim proste w odbiorze, gromadzą bardzo dużo określeń, nazw zastępczych dla Boga, Jezusa, Maryi, epitetów i połączeń wyrazowych, które bezpośrednio przybliżają i powielają szeroko rozumiany obraz sacrum ${ }^{15}$ i uzupełniający

${ }^{15}$ Dobrym przykładem byłyby tu choćby litanie, które nie były przedmiotem niniejszych badań z racji tego, że nie chodzi prymarnie o utwory śpiewane przez młodzież i nie znajdujące się w analizowanym materiale. 
go obraz stosunku Bóg-człowiek. Teksty polskie i czeskie znacząco nie różnią się od siebie w ogólnym przedstawieniu sacrum, jego obrazie, jednak możemy zauważyć pewne specyficzne cechy, jak np. odwołania do Maryi jako Królowej Polski i ogólnie mocniej zarysowany obraz Maryi w polskich tekstach, liczniejsze występowanie pieśni dotyczących jej osoby niż w tekstach czeskich. Związane jest to z realiami polskimi i znaczącym miejscem Matki Bożej w historii i tradycji państwa polskiego. Również obraz Boga w polskich tekstach jest zarysowany mocniej, z większą częstotliwością i bardziej szczegółowo, aniżeli w czeskich. Ogólnie polskie teksty bardziej szczegółowo przedstawiają ogólny obraz Boga, Maryi, Jezusa niż teksty czeskie, bowiem skupiają się bardziej na statycznym opisie sacrum, gromadzą większą ilość przymiotników, metafor, peryfraz. Teksty czeskie w odróżnieniu od tego bardziej skupiają się na przedstawieniu pośredniego obrazu świętości poprzez przybliżenie czynności i postawy, jaką człowiek powinien względem sacrum przyjąć. Czeskie teksty wydają się przez to bardziej dynamiczne, co idzie w parze z częstym gromadzeniem czasowników w trybie rozkazującym, np.: přijd' Pane; napľ̆ mne; naplňuj mne Duchem; osvobod' nás pravdou; oslavujme Hospodina. Teksty czeskie więcej miejsca poświęcają wyobrażeniu Jezusa niż Boga, odwrotnie niż w tekstach polskich, gdzie obraz Boga jest zarysowany mocniej. Teksty polskie więcej miejsca poświęcają przedstawieniu ciągłości i trwałości Boga, w tychże tekstach występuje również Bóg jako istota tajemnicza i niedostępna. Cechy tajemniczości i niedostępności czeskie teksty nie poruszają. To, co jednoznacznie łączy utwory polskie i czeskie, to przedstawianie szeroko rozumianego sacrum w kontekście światła i światłości. W obu językach wyobrażeniom Boga, Jezusa, Maryi, Ducha Świętego towarzyszy właśnie światłość, dalej wspólny jest podstawowy i ogólnie znany obraz sacrum, przykładowo przedstawienie Jezusa jako Dobrego Pasterza i jedynej właściwej drogi do Boga i zbawienia, nieskończoność i wieczność Boga, podkreślenie sprawiedliwości Boga, obecność przebaczenia za grzechy, w końcu choć marginalnie zaznaczony, jednak obecny obraz istot piekielnych jako przez Boga lub Jezusa pokonanych.

\section{Bibliografia}

Anusiewicz, Janusz (1994) Lingwistyka kulturowa. Zarys problematyki. Wrocław: Wydawnictwo Uniwersytetu Wrocławskiego.

Bartmiński, Jerzy (2012) Językowe podstawy obrazu świata. Lublin: Wydawnictwo Uniwersytetu Marii Curie-Skłodowskiej. 
Bartmiński, Jerzy (1999) „Punkt widzenia, perspektywa, językowy obraz świata”. [W:] Jerzy Bartmiński (red.) Językowy obraz świata. Lublin: Wydawnictwo Uniwersytetu Marii Curie-Skłodowskiej.

Bartmiński, Jerzy, Ryszard Tokarski (1986) „Językowy obraz świata a spójność tekstu”. [W:] Teresa Dobrzyńska (red.) Teoria tekstu. Zbiór studiów. Wrocław: Zakład Narodowy im. Ossolińskich.

Grzegorczykowa, Renata (1999) „Pojęcie językowego obrazu świata”. [W:] Jerzy Bartmiński (red.) Językowy obraz świata. Lublin: Wydawnictwo Uniwersytetu Marii CurieSkłodowskiej.

Kałamarz, Wojciech „Śpiewy religijne w liturgii Kościoła” [pobrane z: http://spiewniksiedleckiego.pl/wp-content/uploads/spiewy-w-liturgii.pdf. Data ostatniego dostępu: 24.02.2020].

Michałowska, Teresa (2000) Średniowiecze. Warszawa: Wydawnictwo Naukowe PWN.

Monturzewska, Maria, Halina Kotarska (1990) Wybrane zagadnienia z psychologii muzyki. Warszawa: Wydawnictwo Szkolne i Pedagogiczne.

Mrowiec, Karol (1978) „Kryteria oceny pieśni kościelnych”. Ruch Biblijny i Liturgiczny, 3; $147-151$.

Padacz, Władysław (1958) „Śpiew i muzyka kościelna w świetle statutów powojennych synodów diecezjalnych". Ruch Biblijny i Liturgiczny, 11 (6); 498-506.

Pawlak, Ireneusz (1973) „Pieśń a piosenka religijna”. Msza święta, 9; 212.

Rojewski, Andrzej (2010) „Śpiew jednogłosowy i pieśń religijna w dokumentach Kościoła i polskich komentarzach z lat 1964-1986". Annales Lublinenses pro Musica Sacra, 1; 357368.

Sojka, Agnieszka (2008) Człowiek i Bóg w pieśni. Studium antropologiczno-pedagogiczne, Kraków: Wydawnictwo Uniwersytetu Jagiellońskiego.

Wysocka, Agnieszka (2000) „Aktywność muzyczna młodzieży w niepublicznych szkołach podstawowych". Edukacyjne dyskursy [pobrane z: http://www.edukacyjne.dyskursy.univ.szczecin.pl/aktywnosc.htm. Data ostatniego dostępu: 27.02.2020].

Ziemiański, Stanisław „Pieśń a piosenka” [pobrane z: http://muzyka-koscielna.pl/piesn-apiosenka/. Data ostatniego dostępu: 24.02.2020]. 